\title{
Implementasi Standar Proses dan Dampak Kognitifnya dalam Pembelajaran Matematika oleh Guru yang Tersertifikasi dan Belum Tersertifikasi
}

\author{
Ari Wibowo Hikmal \\ Program Studi Pendidikan Matematika, Fakultas IImu Pendidikan dan Keguruan, Universitas \\ Sawerigading Makassar \\ Jl. Kandea No.127, Bontoala Tua, Makassar, 90213, Sulawesi Selatan \\ E-mail: arhyhikmal188@gamil.com
}

\author{
Article History: \\ Received: dd-mm-yyyy; Received in revised form: dd-mm-yyyy; Accepted: dd-mm-yyyy; \\ Available online: dd-mm-yyyy
}

\begin{abstract}
The problems due to the finding of the tendency of teachers to carry out the teaching and learning process are not in accordance with the learning plan that has been made and the discrepancies between learning devices in this case the learning implementation plan (RPP) made by the teacher with the ongoing teaching and learning process. This type of research is descriptive qualitative which aims to describe the implementation of process standards (planning, implementation, assessment) and their cognitive impact on Mathematics learning by teachers of Makassar 21 Middle School that are certified and not yet certified. The results show that (1) standard process implementation in Mathematics learning by teachers certified in (a) Mathematics learning planning by HASMTK and ROSMTK subjects is in the Good assessment category, (b) implementation of Mathematics learning activities by HASMTK subjects and ROSMTK in the Very Good assessment category, (c) assessment of Mathematics learning activities by HASMTK and ROSMTK subjects in the Very Good assessment category. (2) student learning achievement taught by certified teachers in Mathematics learning (a) HASMTK subjects are in the High category, but the average value of students taught by the subject does not meet classical standards. (b) the subject of ROSMTK is in the High category and the average value of students taught by the subject meets classical standards. (3) the implementation of process standards in Mathematics learning by teachers who have not been certified in (a) Mathematics learning planning by ELMTK subjects is in the Good rating category, (b) the implementation of Mathematics learning activities by ELMTK subjects is in the Very Good assessment category, (c) the assessment of Mathematics learning activities by ELMTK subjects is in the Very Good assessment category. (4) learning achievement of students taught by teachers who have not been certified in Mathematics learning, by ELMTK subjects are in the High category. however, the average value of students taught by the subject does not meet classical standards
\end{abstract}

Keywords: Standard Process; Cognitive Impact; Mathematics Learning; Teacher Certification.

\begin{abstract}
Abstrak
Adapun permasalahan karena adanya ditemukan kecenderungan guru dalam melakukan proses belajar mengajar tidak sesuai dengan rencana pembelajaran yang telah dibuatnya serta ketidaksesuaian antara perangkat pembelajaran dalam hal ini rencana pelaksanaan pembelajaran (RPP) yang dibuat guru dengan proses belajar mengajar yang sedang berlangsung. Jenis penelitian ini adalah deskriptif kualitatif yang bertujuan untuk
\end{abstract}


mendeskripsikan implementasi standar proses (perencanaan, pelaksanaan, penilaian) dan dampak kogniifnya dalam pembelajaran Matematika oleh guru SMP Negeri 21 Makassar yang tersertifikasi dan belum tersertifikasi.. Hasil penelitian menunjukkan bahwa (1) implementasi standar proses dalam pembelajaran Matematika oleh guru yang tersertifikasi pada (a) perencanaan pembelajaran Matematika oleh subjek HASMTK dan ROSMTK berada dalam kategori penilaian Baik, (b) pelaksanaan kegiatan pembelajaran Matematika oleh subjek HASMTK dan ROSMTK berada dalam kategori penilaian Amat Baik, (c) penilaian kegiatan pembelajaran Matematika oleh subjek HASMTK dan ROSMTK berada dalam kategori penilaian Amat Baik. (2) prestasi belajar siswa yang diajar oleh guru tersertifikasi dalam pembelajaran Matematika (a) subjek HASMTK berada dalam kategori Tinggi, akan tetapi nilai rata-rata peserta didik yang diajar oleh subjek tidak memenuhi standar klasikal. (b) subjek ROSMTK berada dalam kategori Tinggi dan nilai rata-rata peserta didik yang diajar oleh subjek memenuhi standar klasikal. (3) implementasi standar proses dalam pembelajaran Matematika oleh guru yang belum tersertifikasi pada (a) perencanaan pembelajaran Matematika oleh subjek ELMTK berada dalam kategori penilaian Baik, (b) pelaksanaan kegiatan pembelajaran Matematika oleh subjek ELMTK berada dalam kategori penilaian Amat Baik, (c) penilaian kegiatan pembelajaran Matematika oleh subjek ELMTK berada dalam kategori penilaian Amat Baik. (4) prestasi belajar siswa yang diajar oleh guru yang belum tersertifikasi dalam pembelajaran Matematika, oleh subjek ELMTK berada dalam kategori Tinggi. akan tetapi nilai rata-rata peserta didik yang diajar oleh subjek tidak memenuhi standar klasikal.

Kata Kunci: Standar Proses; Dampak Kognitif; Pembelajaran Matematika; Sertifikasi Guru.

\section{Pendahuluan}

Peraturan Pemerintah Nomor 19 tahun 2005 tentang Standar Nasional Pendidikan mengemukakan bahwa, salah satu standar yang harus dikembangkan adalah standar proses ${ }^{1}$. Standar proses adalah standar nasional pendidikan yang berkaitan dengan pelaksanaan pembelajaran pada satuan pendidikan untuk mencapai kompetensi lulusan. Pencapaian tersebut tentunya tidak lepas dari peran guru. Guru merupakan tenaga profesional yang berfungsi meningkatkan martabat dan peran guru sebagai agen pembelajaran serta untuk meningkatkan mutu pendidikan nasional.

Guru memiliki kedudukan sebagai tenaga profesional pada jenjang pendidikan dasar, pendidikan menengah, dan pendidikan anak usia dini pada jalur pendidikan formal yang diangkat sesuai dengan peraturan perundangundangan. Guru profesional harus memiliki kualifikasi akademik minimum sarjana (S-1) atau diploma empat (D-IV), yang dibuktikan dengan ijazah sesuai dengan jenis, jenjang, dan satuan pendidikan formal di tempat penugasan. Menguasai kompetensi guru yang mencakup penguasaan kompetensi pedagogik, profesional, kepribadian, dan sosial yang dibuktikan dengan sertifikat pendidik yang diperoleh melalui sertifikasi.

\footnotetext{
${ }^{1}$ Republik Indonesia, "Peraturan Pemerintah Nomor 19 Tahun 2005 Tentang Standar Nasional Pendidikan," 2005, https://peraturan.bpk.go.id/Home/Download/38649/PP\%20NO\%2019\%20TH\%202005.p df.
} 
Terlaksananya sertifikasi guru, diharapkan akan berdampak pada meningkatnya mutu pembelajaran dan mutu pendidikan secara berkelanjutan. Kinerja guru yang tinggi diyakini mampu mempengaruhi tumbuhnya semangat dalam diri guru untuk selalu memperbaiki cara kerjanya yang sekaligus menjadi sumber utama munculnya perilaku yang produktif2.

Guru yang professional dan produktif merupakan salah satu factor penting dalam pendidikan. Sebab guru merupakan sosok yang langsung berhadapan dengan peserta didik pada kegiatan pembelajaran di kelas. Oleh karena itu, penting bagi guru untuk memiliki kualifikasi, kompetensi, serta dedikasi yang tinggi dalam menjalankan tugas profesionalnya ${ }^{3}$.

Nurhattati (2017) mengemukakan bahwa sertifikasi guru memliki pengaruh terhadap kinerja guru. Kinerja guru yang telah tersertifikasi telah mendekati standar yang diinginkan 4 . Penelitian tersebut sejalan juga dengan penelitian yang dilakukan oleh. Budiman (2018) yang menemukan sertifikasi guru berperan secara signifikan terhadap pencapaian kinerja guru ${ }^{5}$. Pengaruh positif tersebut dipertegas oleh Hermawan (2017) yang menyatakan bahwa secara teoritis, proses sertifikasi yang dilakukan dengan benar akan berkontribusi positf terhadap peningkatan mutu pendidikan' ${ }^{6}$.

Dengan demikian, berdasarkan hal tersebut, maka menarik untuk melakukan penelitian lebih lanjut tentang implementasi standar proses (perencanaan, pelaksanaan, dan penilaian) dalam pembelajaran Matematika oleh guru yang tersertifikasi dan belum tersertifikasi, serta mengetahui sejauh mana tingkat prestasi belajar peserta didik yang diajar oleh guru yang tersertifikasi dan belum tersertifikasi di SMP Negeri 21 Makassar.

2 Y Hartijasti, "Hubungan Antara Komitmen Organisasi Dengan Kinerja Perusahaan," Phronesis 3, no. 5 (2002).

3 Kunandar, Guru Profesional Dan Implementasi Kurikulum Tingkat Satuan Pendidikan (Jakarta: Gajah Grafindo Persada, 2007).

${ }^{4}$ Nurhattati Fuad, "Pengaruh Sertifikasi Guru Terhadap Peningkatan Kinerja Guru PAI Di SMP Dan MTs," Jurnal Manajemen Pendidikan 8, no. 1 (July 1, 2017): 23-32, https://doi.org/10.21009/jmp.08103.

${ }^{5}$ Budiman Budiman, "Peranan Penerapan Sertifikasi Guru Terhadap Kinerja Guru (Integrasi Psikologi Industri Dan Organisasi Islami)," Psikis : Jurnal Psikologi Islami 4, no. 1 (June 8, 2018): 74-81, https://doi.org/10.19109/psikis.v4i1.2056.

6 Darman Hermawan, "Profesionalisasi Dan Sertifikasi Guru Dalam Meningkatkan Mutu Pendidikan," Jurnal Administrasi Pendidikan 5, no. 1 (April 10, 2017), http://ejournal.upi.edu/index.php/JAPSPs/article/view/6179. 


\section{Metode}

Penelitian ini adalah penelitian Deskriptif Kualitatif yang dilaksanakan di SMP Negeri 21 Makassar. Subjek penelitian berjumlah 3 orang dan terbagi menjadi 2 kelompok yaitu 2 Guru SMP Negeri 21 Makassar yang tersertifikasi dan 1 Guru SMP Negeri 21 makassar yang belum tersertifikasi. Pengumpulan data dilaksanakan dengan menggunakan lembar observasi dan pedoman wawancara. Pada saat pengumpulan data penelitian di SMP Negeri 21 Makassar, peneliti dibantu oleh observer yakni Pengawas dan Kepala SMP Negeri 21 Makassar. Data yang telah dikumpulkan dianalisis dengan teknik analisis data deskriptif kualitatif, yang dilakukan secara terus menerus dengan aktivitas analisis data yaitu: data reduction (mereduksi data), data display (menyajikan data), dan conclution draing/verification (verifikasi/menyimpulkan).

\section{Implementasi Standar Proses dalam Pembelajaran Matematika}

Aplikasi standar proses perencanaan, pelaksanaan, dan penilaian kegiatan pembelajaran Matematika oleh guru tersertifikasi HASMTK dan ROSMTK pada aspek perencanaan berada pada kategori Baik, pada aspek pelaksanaan kegiatan pembelajaran Subjek HASMTK dan ROSMTK berada pada kategori Amat Baik,

Aplikasi standar proses perencanaan, pelaksanaan, dan penilaian kegiatan pembelajaran Matematika oleh guru yang belum tersertifikasi pada aspek perencanaan berada pada kategori Baik, pada aspek pelaksanaan kegiatan pembelajaran Subjek ELMTK berada pada kategori Amat Baik, pada aspek penilaian kegiatan pembelajaran Matematika subjek HASMTK berada pada kategori Amat Baik, dengan indikator membantu peserta didik untuk memahami konsep materi pembelajaran matematika.

\section{Sertifikasi Guru dan Dampak Kognitifnya terhadap Peserta Didik}

Secara umum, deskripsi standar proses dan dampak kognitifnya terhadap peserta didik yang diajar oleh guru yang tersertifikasi dan belum tersertifikasi di SMP Negeri 21 Makassar dapat dilihat pada Tabel 1 berikut.: 
Tabel 1. Deskripsi Standar Proses Masing-Masing Subjek

\begin{tabular}{|c|c|c|c|c|c|}
\hline & Subjek & $\begin{array}{l}\text { Deskripsi } \\
\text { standar } \\
\text { Proses }\end{array}$ & $\begin{array}{c}\text { Data Hasil } \\
\text { Persentase standar } \\
\text { proses }\end{array}$ & $\begin{array}{l}\text { Dampak } \\
\text { Kognitif }\end{array}$ & Ketutasan \\
\hline $\begin{array}{l}\text { Guru } \\
\text { Ters } \\
\text { etifi } \\
\text { kasi }\end{array}$ & $\begin{array}{l}\text { 1. Subjek } \\
\text { HASMTK } \\
\text { (tersertifi } \\
\text { kasi } \\
\text { selama } 4 \\
\text { tahun) }\end{array}$ & $\begin{array}{l}\text { a. } \begin{array}{l}\text { Pada aspek } \\
\text { perencanaan } \\
\text { kategori } \\
\text { Baik }\end{array} \\
\text { b. Pada aspek } \\
\text { pelaksanaan } \\
\text { Amat Baik, } \\
\text { c. Pada aspek } \\
\text { penilaian } \\
\text { Amat Baik }\end{array}$ & $\begin{array}{c}71 \% \text { dan } \\
\text { terletak pada } \\
\text { interval } 50 \%<\mathrm{P} \leq \\
75 \% \\
94 \% \text { dan } \\
\text { terletak pada } \\
\text { interval } 75 \%<\mathrm{P} \\
\leq 100 \% \\
85 \% \text { dan } \\
\text { terletak pada } \\
\text { interval } 75 \%<\mathrm{P}\end{array}$ & $\begin{array}{c}\text { rata-rata } \\
\text { nilai } \\
\text { hasil tes } \\
\text { prestasi } \\
\text { belajar } \\
\text { berada } \\
\text { pada } \\
\text { kategori } \\
\text { "Sedang" }\end{array}$ & $\begin{array}{c}39 \text { Peserta } \\
\text { didik, Nilai } \\
\text { rata-rata } \\
69.95 \text { dan } \\
\text { interval } \\
61-75, \\
\text { terdapat } \\
82.05 \% \\
\text { peserta } \\
\text { yang tuntas } \\
\text { belajar }\end{array}$ \\
\hline & $\begin{array}{l}\text { 2. Subjek } \\
\text { ROSMTK } \\
\text { (tersertifi } \\
\text { kasi } \\
\text { selama } 3 \\
\text { tahun) }\end{array}$ & $\begin{array}{l}\text { a. Pada aspek } \\
\text { perencanaan } \\
\text { kategori } \\
\text { Baik } \\
\text { b. Pada aspek } \\
\text { pelaksanaan } \\
\text { Amat Baik, } \\
\text { c. Pada aspek } \\
\text { penilaian } \\
\text { kategori } \\
\text { Amat Baik }\end{array}$ & $\begin{array}{c}\leq 100 \% \\
71 \% \text { dan } \\
\text { terletak pada } \\
\text { interval } 50 \%<\mathrm{P} \leq \\
75 \% \\
96 \% \text { dan } \\
\text { terletak pada } \\
\text { interval } 75 \%<\mathrm{P} \\
\leq 100 \% \\
89 \% \text {, interval } 75 \% \\
<\mathrm{P} \leq 100 \%\end{array}$ & $\begin{array}{l}\text { Rata- } \\
\text { rata nilai } \\
\text { hasil tes } \\
\text { prestasi } \\
\text { belajar } \\
\text { yang } \\
\text { diajar } \\
\text { oleh } \\
\text { subjek } \\
\text { berada } \\
\text { pada } \\
\text { kategori } \\
\text { Sedang }\end{array}$ & $\begin{array}{c}36 \text { Peserta } \\
\text { didik, rata- } \\
\text { rata hasil } \\
\text { tes prestasi } \\
\text { belajar } \\
75.11 \text { dan } \\
\text { interval } 65 \\
-84, \\
\text { terdapat } \\
86.11 \% \\
\text { peserta } \\
\text { didik yang } \\
\text { telah tuntas } \\
\text { belajar. }\end{array}$ \\
\hline $\begin{array}{l}\text { Guru } \\
\text { yang } \\
\text { Belu } \\
\text { m } \\
\text { Ters } \\
\text { etifi } \\
\text { kasi }\end{array}$ & $\begin{array}{l}\text { 3. Subjek } \\
\text { ELMTK } \\
\text { (menjadi } \\
\text { guru dan } \\
\text { terangkat } \\
\text { sebagai } \\
\text { PNS } \\
\text { kurang } \\
\text { lebih } \\
\text { selama 4 } \\
\text { tahun) }\end{array}$ & $\begin{array}{l}\text { a. Pada aspek } \\
\text { perencanaan } \\
\text { kategori } \\
\text { Baik } \\
\text { b. Pada aspek } \\
\text { pelaksanaan } \\
\text { kategori } \\
\text { Amat Baik, } \\
\text { c. Pada aspek } \\
\text { penilaian } \\
\text { kategori } \\
\text { Amat Baik }\end{array}$ & $\begin{array}{l}88 \% \text { dan terletak } \\
\text { pada interval } 75 \% \\
<\mathrm{P} \leq 100 \%\end{array}$ & $\begin{array}{l}\text { Rata- } \\
\text { rata nilai } \\
\text { hasil } \\
\text { belajar } \\
\text { yang } \\
\text { diajar } \\
\text { oleh } \\
\text { subjek } \\
\text { berada } \\
\text { pada } \\
\text { kategori } \\
\text { "Sedang" }\end{array}$ & $\begin{array}{l}40 \text { Peserta } \\
\text { didik, } \\
\text { Nilai rata- } \\
\text { rata hasil } \\
\text { tes prestasi } \\
\text { belajar } \\
69.80, \\
\text { terdapat } \\
75 \% \\
\text { peserta } \\
\text { didik yang } \\
\text { telah tuntas } \\
\text { belajar. }\end{array}$ \\
\hline
\end{tabular}




\section{Penutup}

\section{Simpulan}

Berdasarkan hasil pengamatan dan pemantauan, maka dapat disimpulkan bahwa: (a) Pada implementasi standar proses oleh guru yang telah tersertifikasi sudah sesuai yang direncanakan. (b) Pada implementasi standar proses oleh guru yang belum tersertifikasi tak kalah dengan guru yang sudah tersertifikasi, namun pada pelaksanaannya masih ada yang tidak tepat alokasi waktu pelaksanaannya (c) Dampak kognitif peserta didik yang diajar oleh guru tersertifikasi yaitu HASMTK dan ROSMTK berada pada kategori "Sedang" Sedangkan data nilai hasil tes prestasi belajar yang diberikan oleh subjek HASMTK dan ROSMTK berada pada kategori "Tinggi"; (d) Dampak kognitif peserta didik yang diajar oleh guru belum tersertifikasi yaitu ELMTK berada pada kategori "Sedang".

Saran

Peneliti menyarankan beberapa yakni; (a) Guru sebaiknya menyusun bahan ajar sendiri, memperhatikan RPP serta melaksanakan pembelajaran sesuai dengan RPP yang telah dibuat, (b) kepada pengelola sekolah dalam hal ini penetapan jumlah rombongan di dalam kelas agar mengikuti penetapan yang telah ditentukan oleh PERMENDIKNAS (c) kepada peneliti berikutnya untuk melakukan penelitian yang lebih luas ruang lingkupnya dengan instrumen PK Guru revisi yang terbaru dengan aturan penggunaan yang resmi dari pemerintah pusat.

\section{Daftar Pustaka}

Budiman, Budiman. "Peranan Penerapan Sertifikasi Guru Terhadap Kinerja Guru (Integrasi Psikologi Industri Dan Organisasi Islami)." Psikis : Jurnal Psikologi Islami 4, no. 1 (June 8, 2018): 74-81. https://doi.org/10.19109/psikis.v4i1.2056.

Fuad, Nurhattati. "Pengaruh Sertifikasi Guru Terhadap Peningkatan Kinerja Guru PAI Di SMP Dan MTs." Jurnal Manajemen Pendidikan 8, no. 1 (July 1, 2017): 23-32. https://doi.org/10.21009/jmp.08103.

Hartijasti, Y. "Hubungan Antara Komitmen Organisasi Dengan Kinerja Perusahaan." Phronesis 3, no. 5 (2002).

Hermawan, Darman. "Profesionalisasi Dan Sertifikasi Guru Dalam Meningkatkan Mutu Pendidikan." Jurnal Administrasi Pendidikan 5, no. $1 \quad$ (April 10, 2017). http://ejournal.upi.edu/index.php/JAPSPs/article/view/6179.

Kunandar. Guru Profesional Dan Implementasi Kurikulum Tingkat Satuan Pendidikan. Jakarta: Gajah Grafindo Persada, 2007.

Republik Indonesia. "Peraturan Pemerintah Nomor 19 Tahun 2005 Tentang Standar Nasional Pendidikan," 2005. https://peraturan.bpk.go.id/Home/Download/38649/PP\%20NO\%201 9\%20TH\%202005.pdf. 